\title{
Pitfalls in erosion level calculation based on remnants of maar and diatreme volcanoes
}

\section{Les pièges de la reconstitution des topographies d'érosion initiales fondée sur les vestiges des maars et diatrèmes volcaniques}

\author{
Károly Németh*, Ulrike Martin**, Gábor Csillag***
}

\begin{abstract}
Erosion estimates based on geometrical dimension measurements of eroded maar/diatreme volcanoes are useful methods to determine syn-volcanic surface level and syn-volcanic bedrock stratigraphy. However, such considerations on volcanic architecture should only be employed as a first-order approach to determine the state of erosion. We demonstrate, on both young and eroded maar/diatreme volcanoes, that establishing the volcanic facies architecture gives vital information on the environment in which the volcano erupted. In 'soft' rocks, maar volcanoes are broad and underlain by 'champagne glass'-shaped diatremes. In contrast, the crater wall of maar volcanoes that erupted through 'hard rocks' will be steep, filled with lacustrine volcaniclastic deposits and underlain by deep diatremes.
\end{abstract}

Key words: monogenetic volcano, maar, tuff ring, diatreme, scoria, phreatomagmatism.

\begin{abstract}
Résumé
L'estimation de l'érosion fondée sur la géométrie des volcans de type maar-diatrème est une méthode applicable à la reconstruction de la surface syn-volcanique et de la stratigraphie de la série sous-jacente. Toutefois les considérations relatives à l'architecture volcanique doivent seulement être utilisées comme une première approche pour déterminer le niveau initial de la surface aujourd'hui érodée. Nous démontrons que la détermination des faciès volcaniques, tant dans les maars-diatrèmes récents que dans les systèmes érodés de ce type, donne des informations fondamentales sur la nature des roches encaissantes au sein desquelles l'éruption volcanique s'est produite. Dans les roches encaissantes meubles, les maars sont larges avec un diatrème sous-jacent en forme de "coupe de champagne ». Au contraire, au sein de roches plus résistantes, les cratères de maars sont entourés de parois raides et bien souvent remplis de dépôts lacustres d'origine volcanoclastique qui masquent des diatrèmes profonds.
\end{abstract}

Mots clés : volcan monogénique, maar, anneau de tuf, diatrème, scorie, phréatomagmatisme.

\section{Version française abrégée}

Dans les champs volcaniques anciens (un à plusieurs millions d'années), les vestiges érodés d'édifices phréatomagmatiques apportent d'importantes informations sur la stratigraphie syn-éruptive des roches encaissantes (Németh, 2003). Le volcanisme dans le secteur occidental du Bassin pannonien, en Hongrie (région Carpatho-pannonienne ; fig. 1) s'est produit durant le Miocène et le Pliocène entre 7,98 and 2,8 Ma (Balogh et al., 1986, 2005 ; Balogh et Németh, 2005). Les structures volcaniques dominantes dans le Bassin occidental pannonien sont représentées par des maars plus ou moins érodés, des anneaux de tuf, des cônes de scories et des volcans-boucliers (Martin and Németh, 2004). Lorsque le magma ascendant rencontre des eaux souterraines, un volcan de type maar se forme (fig. 2), bientôt entouré par les dépôts horizontaux de téphras éjectés (Vespermann and Schmincke, 2000). Le plancher du cratère de maar recoupe la surface syn-éruptive (fig. 2). Les coupes transversales de maars révèlent souvent quatre parties distinctes (Lorenz, 1986 ; White, 1991b) : 1) la zone source ou « racine» (Lorenz, 2000) ; 2) le diatrème inférieur ; 3) le diatrème supérieur et 4) le lac de cratère (fig. 2). Les différentes zones d'un maar sont normalement exposées selon le niveau d'érosion ayant affecté le relief environnant (fig. 3).

La présence et l'identification de pépérites indiquent une activité volcanique et une sédimentation simultanées, cette observation apportant un éclairage sur la nature du trans-

\footnotetext{
* Massey University, Volcanic Risk Solutions, INR, PO Box 11 222, Palmerston North, New Zealand. E-mail: k.nemeth@massey.ac.nz

** Würzburg University, Institut für Geologie, Pleicherwall 1,97070 Würzburg, Germany. E-mail: ceboruco@web.de

*** Geological Institute of Hungary, Stefánia út 14, Budapest, H-1143 Hungary. E-mail: csillag@mafi.hu
} 
port du magma à faible profondeur et sur les propriétés du sédiment-hôte au moment de l'éruption (Skilling et al., 2002). Les pépérites, lorsqu'elles sont associées au volcanisme de type phréatomagmatique, peuvent se développer 1) lorsque les dykes d'alimentation pénètrent les sédiments saturés en eau remplissant le cratère de maar ou le bassin ceinturé par l'anneau de tuf ; 2) près des évents, et/ou 3) en bordure des coulées de lave. Cependant, la position initiale des coulées de lave a besoin d'être reconstituée avec précision avant d'en déduire toute conclusion d'ordre géomorphologique (fig. 4 et fig. 5). Dans le Bassin pannonien, Martin and Németh (2004) ont reconnu le fait qu'une partie des vastes buttes recouvertes de lave correspondaient à des ensembles intrusifs de faible profondeur, alimentés par des réseaux complexes de sills et dykes. L'interprétation morphologique correcte de tels ensembles magmatiques à roche cohérente est essentielle afin de pouvoir déterminer le niveau d'érosion sur les unités préservées (fig. 5). Habituellement, lors des phases finales de l'activité phréatomagmatique, les coulées de lave tendent à s'accumuler dans le cratère. Pour les maars profonds, la base de telles coulées peut se retrouver ainsi à des centaines de mètres sous la paléosurface synéruptive (fig. 6). Dans le cas d'une érosion prolongée et lorsque seules les buttes résiduelles sont préservées, la distinction entre les vestiges de coulées dérivées de sources inconnues ou coulées issues de l'éruption au sein d'un cratère, et les corps intrusifs à roche cohérente est un élément crucial pour la détermination de la position initiale de la paléosurface syn-éruptive du maar. Les anneaux de tuf et les maars de large dimension peuvent également contenir d'épaisses couches de sédiments lacustres, accumulées sur de longues périodes (milliers d'années) dans leur cratère. Ces sédiments lacustres sont généralement poreux et humides, réduisant ainsi l'épaisseur de la succession stratigraphique de façon significative avec le temps (fig. 7 ; Suhr et al., 2004). La subsidence progressive et la compaction de la séquence remplissant le cratère doivent être prises en compte si l'on veut obtenir une estimation correcte de la position de la surface syn-volcanique (fig. 8). Un cratère de maar de grande dimension peut être comblé par une quantité non négligeable d'eau (dizaines de mètres de profondeur). Dans les lacs de cratère, lorsque l'activité volcanique reprend, des éruptions se produisent dans un milieu purement subaquatique ou émergeant. Après une longue période durant laquelle l'érosion est active, la séquence sédimentaire préservée peut donner l'impression que les éruptions ont pris place dans un environnement entièrement subaquatique (fig. 9 et fig. 10).

Il est indispensable de reconstruire l'évolution géomorphologique de la région afin de pouvoir distinguer les milieux sédimentaires purement liés à l'environnement du bassin, de ceux créés par les éruptions volcaniques (fig. 11). Dans la littérature, on écrit souvent que la forme et la géométrie des volcans de petite taille dépendent fortement des conditions du substratum et des roches encaissantes au sein desquelles le volcan fait éruption (Lorenz, 2003a,b) et où des cratères de faible profondeur, aplatis et évasés se construisent (fig. 12). En revanche, dans les milieux consti- tués de roches dures (fig. 12), les parois du cratère demeurent stables et la zone source (racine) peut atteindre une profondeur bien plus grande (Lorenz, 2003a). Il importe de reconnaître avec précision les champs volcaniques qui sont érodés afin de pouvoir distinguer les formes de relief volcaniques associées à des roches encaissantes spécifiques. Nous suggérons qu'au lieu d'utiliser une approche géométrique pour établir la position originale des paléosurfaces syn-éruptives, une étude approfondie des roches pyroclastiques préservées et des relations entre les différents faciès devrait conduire à une meilleure compréhension de : 1) l'environnement éruptif au sein duquel le volcan s'est développé, 2) la distinction entre les processus extra- and intra-cratériques, 3) l'identification des caractéristiques texturales telles que l'apparition de pépérite pouvant indiquer des conditions spécifiques de milieu au sein duquel les émissions de lave se sont produites, et enfin $4^{\circ}$ ) l'identification des roches encaissantes formant le substratum et le cadre environnant les volcans en activité.

\section{Introduction}

Small-volume volcanic eruptions are commonly associated with monogenetic constructional volcanic landforms such as tephra cones, tephra rings, or tephra mounds consisting of bedded pyroclastic deposits that have been emplaced by fallout, density currents and/or by the down slope remobilisation of tephra (Connor and Conway, 2000; Vespermann and Schmincke, 2000). Monogenetic volcanic fields often include deposits related to explosive eruptions (e.g. phreatomagmatism) driven by violent magma-water interaction where intruding magma encounters shallow or deep groundwater and/or surface water sources (White, 1991a). In many cases, seasonal climatic changes as well as the amount of available surface and ground water determine the type of volcanic landforms constructed (Aranda-Gomez and Luhr, 1996; Németh et al., 2001). For these reasons a great variety of volcanic landforms are expected to develop, especially in low lying areas where the hydrogeology of the country rocks may be complex (White, 1990). The resulting volcanic landforms in such settings are strongly dependent on the nature of the pre-eruptive surface, the lithology and mechanical properties of volcanic conduit wall rocks, vent geometry, and the availability and type of external water (Lorenz, 1987). Erosion exposes the inner architecture of monogenetic volcanoes revealing volcanic lithofacies that provides important information on the eruptive mechanisms involved in the construction of the volcano (Lorenz, 2000). Monogenetic volcanic fields commonly consist of large numbers of edifice clusters and/or alignments that may include hundreds of single maars or cones (Connor and Conway, 2000). Over the life of a volcanic field (thousands to millions of years) individual edifices may erode significantly, leading to a diminishing number of variably eroded landforms preserved on a gradually degraded landscape (White, 1991b; Konecny and Lexa, 2000; Németh and White, 2003; Lorenz and Haneke, 2004). Over longer time periods, a relatively uniform landscape can be dissected, lowered and commonly inverted, showing preserved clusters 
of formerly low-lying structures emerging in elevated positions (Németh and Martin, 1999). Especially volcanic erosion may result in remnants of volcanoes of similar age forming clusters and this may enable a geomorphic horizon for that time to be identified (Németh and Martin, 1999). A refined erosion history of large (hundreds of $\mathrm{km}^{2}$ ) volcanic areas can be reconstructed when there is a substantial number of age clusters of volcanic remnants defined by good quality age data. In this geomorphic reconstruction, geomorphic data on erosion trends for certain types of volcanic landforms such as scoria cones, tuff rings, tuff cones and maars are critical.

There are many ways to reconstruct the erosional profile of a particular monogenetic landform, and therefore, to estimate the erosion stage of the syn-eruptive landscape on which such a volcano erupted. In ancient volcanic fields (Ma old), erosional remnants of phreatomagmatic volcanoes provide important information on the syn-eruptive country rock stratigraphy (Németh, 2003). In this paper we present a detailed study leading to the understanding of 3D relationships between preserved volcanic facies on phreatomagmatic volcanoes, a fundamental step for estimating erosion rates on the surrounding landscape. We also demonstrate that maar volcanoes can create their 'own' sedimentary environment that reflects different eruption environments with regard to the surrounding syn-volcanic landscape.

\section{Geological settings}

Numerous examples of intra-continental volcanic fields that have evolved in a low-lying fluvio-lacustrine basin show irregularities when their erosion history is reconstructed. In this context phreatomagmatic processes dominate the fragmentation history of the uprising magma. Volcanism in the western segment of the Pannonian Basin, Hungary in the Carpatho-Pannonian region (fig. 1) occurred during the Miocene and Pliocene between 7.98 and 2.8 Ma (Balogh et al., 1986, 2005; Balogh and Németh, 2005). In the Bakony - Balaton Highland Volcanic Field, different volcanoes can be grouped together by their space-time relationship (Németh and Martin, 1999). Dominant volcanic landforms in the western Pannonian Basin are variously eroded maars, tuff rings, scoria cones, and shield volcanoes (Martin and Németh, 2004). The basement of the western Pannonian Basin volcanic fields consists of Silurian schists, Permian red sandstone and Mesozoic carbonaceous beds for the Bakony - Balaton Highland Volcanic Field. The basement of the Little Hungarian Plain Volcanic Field is composed of Paleozoic to Mesozoic metamorphic rocks. In each area the immediate underlying rock units comprise variable thicknesses of Miocene quartzo-feldspathic siliciclastic sediments deposited from a shallow marine to fluvio-lacustrine

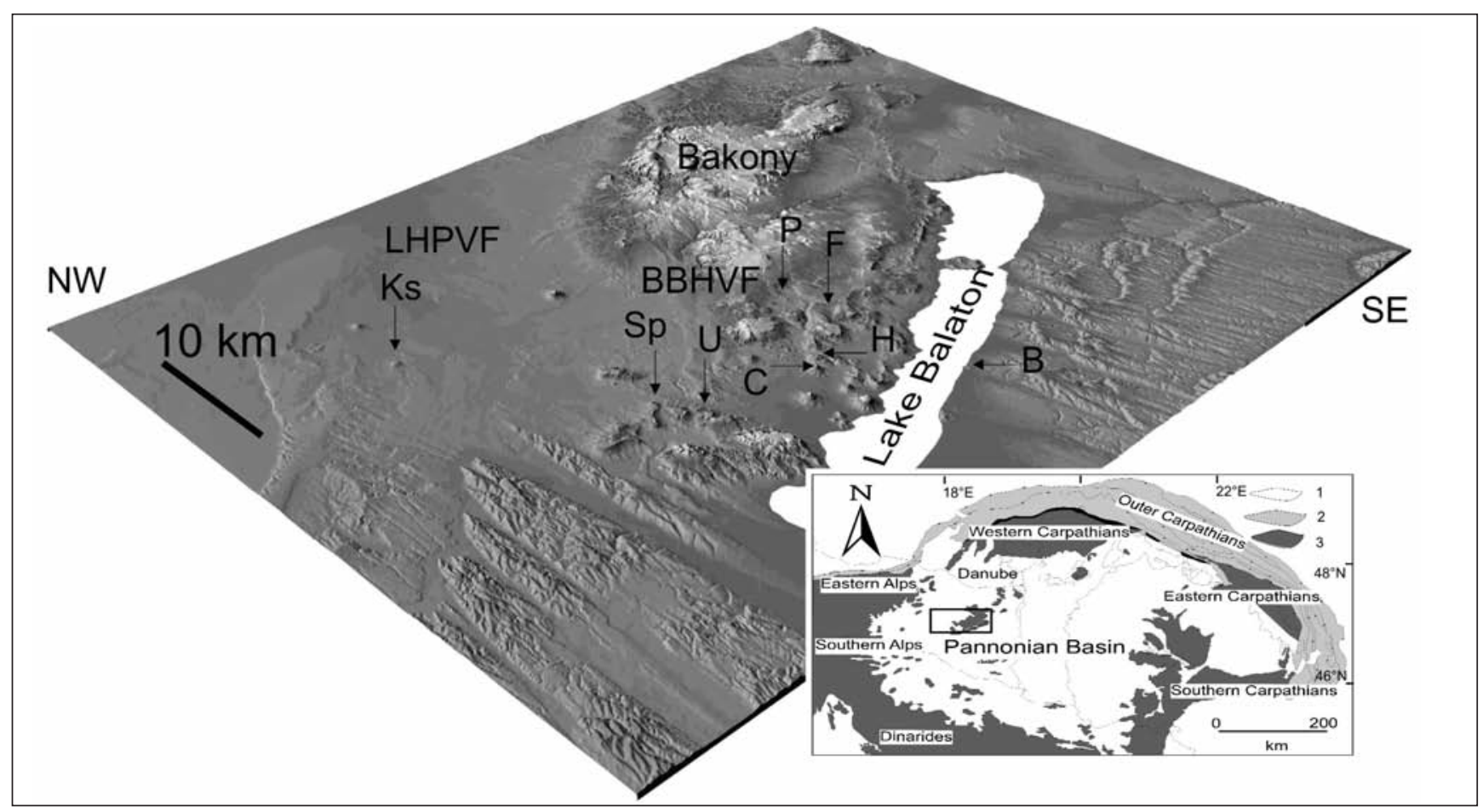

Fig. 1 - Oblique view from the SW over western Hungary. LHPVF: Little Hungarian Plain Volcanic Field; BBHVF: Bakony-Balaton Highland Volcanic Field; Ks: Kissomlyó; Sp: Sümegprága; U: Uzsa; P: Pula; F: Fekete-hegy; B: Boglár; H: Hajagos; C: Csobánc. Inset map shows the Carpatho-Pannonian region with the major geological units. 1: Cenozoic units; 2: Outer Carpathian flysch nappes; 3: Mesozoic or older rocks on the surface.

Fig. 1 - La Hongrie occidentale, vue oblique du sud-ouest. LHPVF : champ volcanique de la petite Plaine hongroise ; BBHVF : champ volcanique de Bakony-Haut-pays de Balaton ; Ks : Kissomlyó ; Sp : Sümegprága ; U : Uzsa ; P : Pula ; F : Fekete-hegy ; B : Boglár ; H : Hajagos ; $C$ : Csobánc. La figure insérée montre les grandes unités géologiques de la région carpatho-pannonienne. $1:$ unités cénozoïques ;2 : nappes de flysch des Carpates externes ; affleurements de roches mésozoïques ou plus anciennes. 
Fig. 2 - A schematic structure of a maar diatreme volcano.

Fig. 2 - Structure schématisée d'un volcan de type maar-diatrème.

environment (Kázmér, 1990; Magyar et al., 1999). The bedrock hydrogeological characteristics have strongly influenced the morphology of the overlying volcanic landforms. In areas where thick Neogene siliciclastic sediments are the pre-volcanic strata, then broad, lensoid shaped maars and tuff rings formed. In contrast, deep maars developed in areas where only thin Neogene siliciclastic beds cover fracture-controlled, karst water-bearing aquifer (Martin and Németh, 2004).

\section{Problem with landforms reconstruction}

When magma interacts with ground water, a hole-in-the-ground maar volcano forms (fig. 2) that is surrounded by flat lying tephra beds (Vespermann and Schmincke, 2000). The crater floors of maars undercut the syn-eruptive surface (fig. 2). Cross sections of maars reveal four distinct parts (Lorenz, 1986; White, 1991b): (1) a root zone consists of magmatic intrusions that often interact with matrix of conduit filling volcaniclastic debris and collapsed blocks of country rocks (Lorenz, 2000); (2) a lower diatreme represents the deep subsurface zone of the conduit and is filled with a mixture of primary and intra-vent volcaniclastic debris; (3) an upper diatreme constructed from near surface primary pyroclastic deposits and; 4) the crater lake setting where sediments of different origin accumulated in a small sedimentary basin, influenced by non-volcanic sedimentation (fig. 2).

The different zones of a maar volcano described above are usually exposed in accordance with the level of erosion that has shaped the surrounding landscape (fig. 3). Therefore a

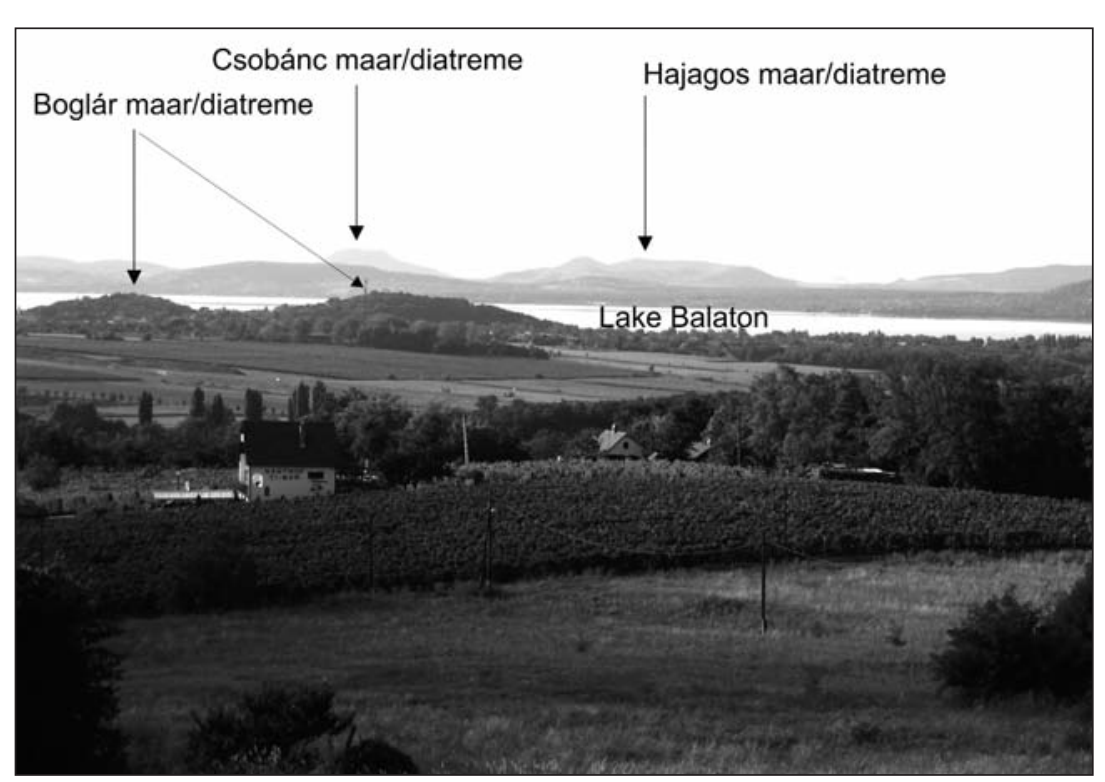

clear identification of the internal architecture of a maar provides vital information on the level of erosion acting on the volcanic landscape. The use of eroded monogenetic volcanic fields to calculate long-term erosion rates and to estimate the paleogeography of a region is a powerful tool to reconstruct the morphology of syn-volcanic landscapes. Finally, maar and diatreme volcanoes are often the only sites where already eroded pre-volcanic sediments may have been preserved, thus providing information on the basement stratigraphy.

Phreatomagmatic explosions contribute to the development of almost every small-volume volcano, especially in valleys where water is largely available (White, 1991a). Subsequent magmatic explosions, however, characterise the waning stage of eruptive activity in such volcanoes. This later phase commonly produces large scoria cones accompanied by lava erupting inside the crater. Phreatomagmatic edifices commonly erupt into fluvio-lacustrine basins, therefore the recognition of such volcanoes in ancient settings strongly suggests that the syn-volcanic landscape was basin-like or a valley. Such an interpretation may alter the extrapolation of the estimated landscape erosion data. It also has recently been highlighted that eruptive activity may restart and reju-

Fig. 3 - Eroded phreatomagmatic volcanoes with exhumed vent zones forming diatremes in western Hungary (black arrows point to diatremes).

Fig. 3 - Volcans phréatomagmatiques érodés avec des cheminées exhumées formant des diatrèmes en Hongrie occidentale (les flèches noires signalent les diatrèmes). 
venate from time to time in volcanoes that were initially considered to be monogenetic sensu stricto (Németh et al., 2003). Recognition of processes that alter the preserved geological record of small-volume volcanoes must be taken into account in order to estimate accurately the erosion of the landscape of syn-eruptive settings. Below, we list a few basic considerations that illustrate how syn-volcanic landscape erosion levels can be misinterpreted.

\section{Extra and intra-crater peperite}

Peperite results from interaction between magma and wet sediment exhibits a range of complex textures (White et al., 2000; Skilling et al., 2002). The presence and recognition of peperite indicate contemporaneous volcanism and sedimentation, and this provides insight into the nature of subsurface magma transport and host-sediment properties at the time of eruption (Skilling et al., 2002). Peperite is common along the margin, adjacent to intrusive bodies and where lava flows travelled through wet sediments (Skilling et al., 2002). Recognition of peperite-forming processes in the sub-surface part of a phreatomagmatic volcano is illustrated at several sites (White and Mcclintock, 2001; Hooten and Ort, 2002). Peperite, in association with phreatomagmatic volcanoes can develop when feeder dykes intrude water-saturated sediment infilling maar or tuff ring basins, vent zones, and/or near lava flow margins. However, these three types of peperite may suggest different construction processes and therefore may lead to different interpretations. In the western Pannonian Basin, lava capped buttes (e.g. Kissomlyó: Martin and Németh, 2005) are commonly accompanied by a great variety of peperite indicating that the lava flows were erupted in a wet environment. However the initial position of the lava flows needs to be carefully established before any geomorphological conclusion is drawn (figs. 4 and 5). In the western Pannonian Basin, most of the

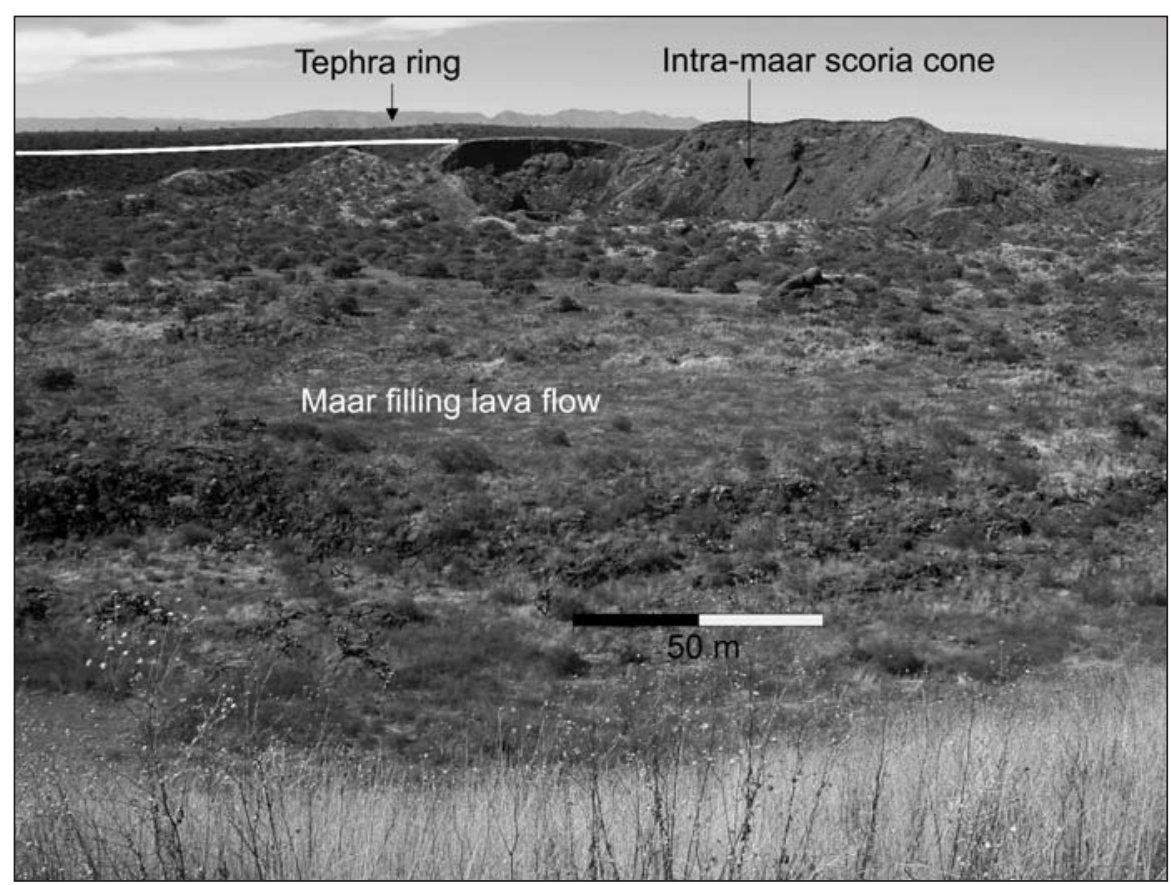

lava flows have erupted inside the crater of a phreatomagmatic volcano. In that particular case, the presence of peperite only means that the crater zone - and not necessarily the surrounding syn-volcanic landscape - was 'wet' and water saturated. The identification of peperite in such settings therefore is not sufficient to validate the reconstruction of the eruptive environment nor the establishment of the syn-volcanic landscape position onto the volcano erupted.

\section{Intra-crater extrusive/intrusive processes}

In the western Pannonian Basin, Martin and Németh (2004) have recognised that many of the larger lava-dominated buttes are shallow intrusive complexes and consist of complex networks of sills and dykes. Correct morphological interpretation of such coherent magmatic bodies is essential in order to determine the erosion level of the preserved units (fig. 5). Without justification of the intrusive versus effusive origin of such coherent magmatic bodies, the reconstruction of the position of the syn-eruptive landscape may lead to a significant error in a range of tens to hundreds of metres. Maar craters, especially if they are dry (not enough inflow of water to the crater after the eruption) and the magma output rate is large enough, could be filled by extensive lava flows as shown by many young maars in arid areas, e.g. in Mexico (fig. 4). In the western part of the Miocene and Pliocene alkaline basaltic volcanic fields of the western Pannonian Basin, coherent magmatic bodies are exposed at depths down to $300 \mathrm{~m}$ below the original syn-eruptive paleosurface. Such intrusive complexes could be associated with eroded volcanic conduits, and this can be used to determine the level of erosion (Martin and Németh, 2004). Phreatomagmatic volcanoes usually produce small scoria cones in their waning eruptive phase when no more water is available to fuel magma-water interaction during the eruption (figs. 4 and 5). In the final stages of volcanic activity lava flows tend to accumulate in the crater. In deep maars, the base of such lava flows could be positioned hundreds of metres below the syneruptive paleosurface (fig. 6). In the case of long-lasting erosion (when only lava capped buttes are preserved) the distinction between lava flow rem-

Fig. 4 - A complex large maar (La Breña) in Mexico. The maar crater has not been filled with water. The tephra ring sits on the syn-volcanic surface (white line) that is well above the top of the maar crater filling lava flows.

Fig. 4 - Un grand maar complexe (La Breña) au Mexique. Le cratère du maar n'a pas été rempli d'eau. L'anneau de téphras se trouve sur la surface synvolcanique (ligne blanche), qui est bien au-dessus du toit des coulées de lave remplissant le cratère du maar. 


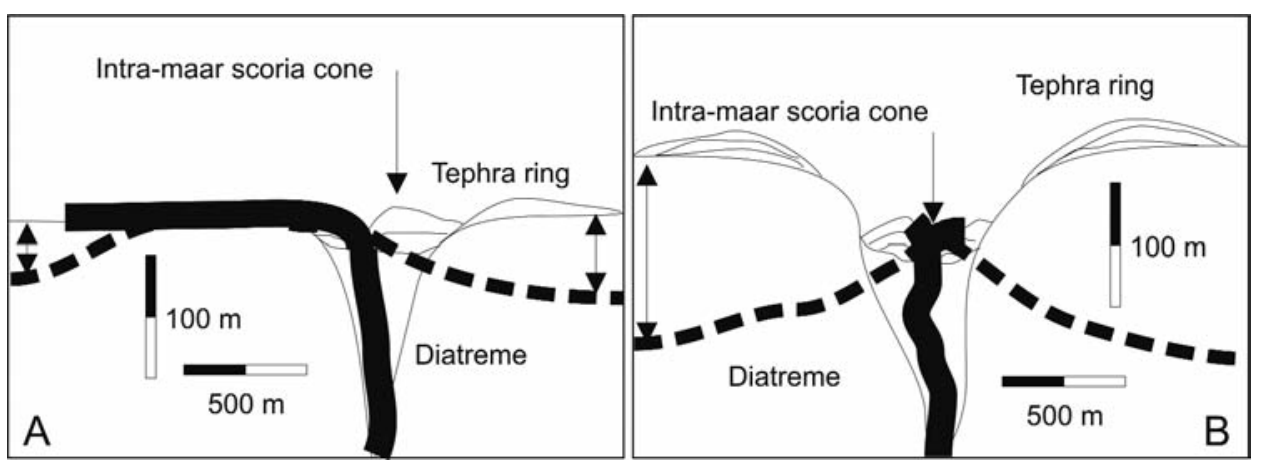

Fig. 5 - Intra-maar scoria cones could be point sources of lava flows that may preserve paleosurfaces. In shallow maars with low tephra rings, scoria cones may grow higher than the tephra rim and lava can flow out onto the syn-eruptive paleosurface (A). In deep maars, scoria cones may initiate intra-crater lava flows (B). To distinguish the two processes and therefore correctly interpret the meaning of the lava flow preserved morphology, detailed mapping is necessary. Dashed lines represent erosional surfaces. Thick blakc lines are coherent magmatic bodies (feeder dykes, lava flows or sills.

Fig. 5 - Des cônes de scories situés à l'intérieur d'un maar peuvent être la source de coulées de lave qui peuvent fossiliser des paléosurfaces. Dans les maars peu profonds, dont l'anneau de téphras est surbaissé, les cônes de scories peuvent dépasser l'anneau de téphras et la lave s'écoule alors sur la paléosurface syn-éruptive (A). Dans les maars profonds, les cônes de scories peuvent produire des coulées de lave à l'intérieur du cratère $(B)$. Un levé géologique détaillé est nécessaire pour distinguer les deux processus et fonder une interprétation correcte de la morphologie préservée par la lave. Les tiretés représentent les surfaces actuelles après érosion. Les lignes noires épaisses désignent des corps magmatiques (dykes d'alimentation, coulées de lave ou sills).

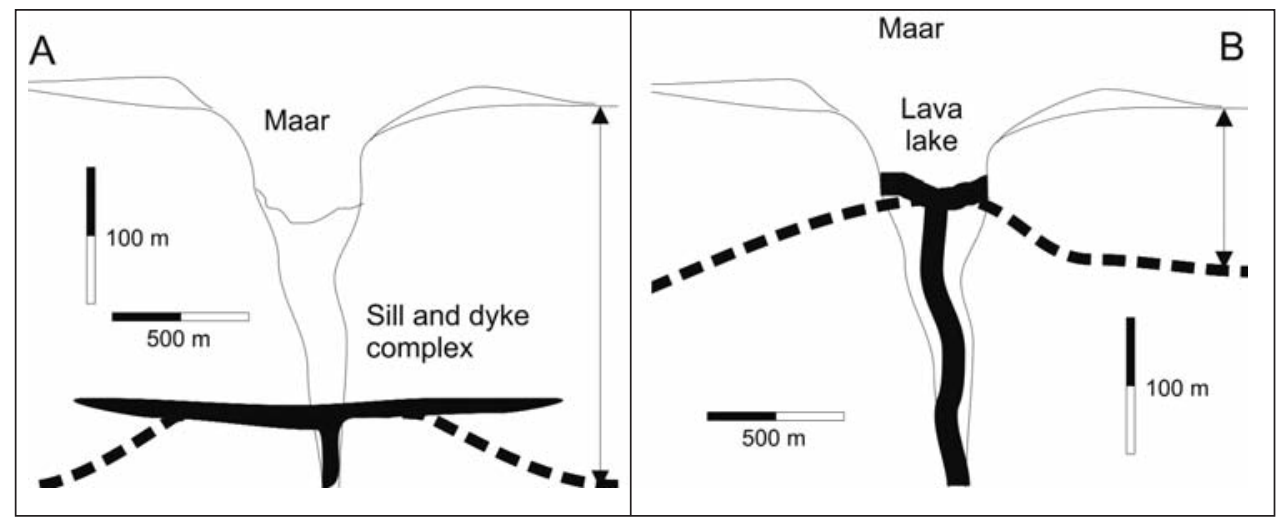

Fig. 6 - Horizontal basalt sheets may be either sills associated with the feeding system of the volcano (A) or lava that has flowed into the dry maar crater (B). Dashed lines represent erosion level.

Fig. 6 - Les nappes de basalte horizontales peuvent représenter soit des sills associés au système d'alimentation du volcan (A) soit des lacs de lave contenus dans les cratères secs des maars (B). Les tirets représentent le niveau atteint par l'érosion.

nants derived from unknown sources and lava flows erupted into a volcanic crater is a key element in reconstructing the position of the syn-eruptive/maar paleosurface. Without considering these types of origin no geomorphological reconstruction can be completed properly.

\section{Intra-crater lacustrine deposits}

Large tuff rings and maars may host significant thicknesses of lacustrine sediments accumulated over a long period of time (thousands of years) in their crater. In the western Pannonian Basin at least three maar craters are known where a few tens of metres of thick lacustrine sediments have been preserved (Martin and Németh, 2004). Such lacustrine sediments are wet, and having significant porosity, the thickness of the succession could be reduced over time. This situation may cause significant subsidence of the crater fill (Suhr et al., 2004). Such lacustrine successions display convolute and distorted beddings, water escape structures (fig. 7) and/or unusual accumulation of blocks (Németh et al., 2002; Csillag et al., 2004). After erosion and exhumation of the lacustrine succession the stratigraphic position can be used to estimate the original level of the syn-eruptive landscape, on which the volcano grew. However, the gradual subsidence and compaction of the crater filling succession must be taken into account for obtaining a correct estimate of the syn-volcanic surface (fig. 8). In any case when subsidence and/or truncation of the lacustrine succession are recognised, the position of the syn-eruptive surface could be significantly higher than the value calculated only on the basis of the size and sedimentary features preserved in the lacustrine succession.

\section{Sedimentary environments 'created' by phreatomagmatic volcanoes}

When a phreatomagmatic volcano forms (e.g. a maar), its crater may reach a few $\mathrm{km}$ in diameter. A crater of this size can be filled with a significant amount of water (tens of metres deep). In crater lakes, when volcanic activity is renewed, eruptions occur in a purely subaqueous or emergent environment. After a long period of erosion, the sedimentary record may give an impression that eruptions took place in a fully subaqueous context. In the western Pannonian Basin, many eroded, small-volume, mafic volcanic complexes (fig. 9) with significant phreatomagmatic eruptive histories are documented (Martin and Németh, 2004). Once the edifices are eroded, volcaniclastic sediments tend to accumulate in crater lakes forming complex sedimentary facies associations similar to those generated under normal subaqueous circumstances (fig. 10). To distinguish between sedimentary environments purely related to 


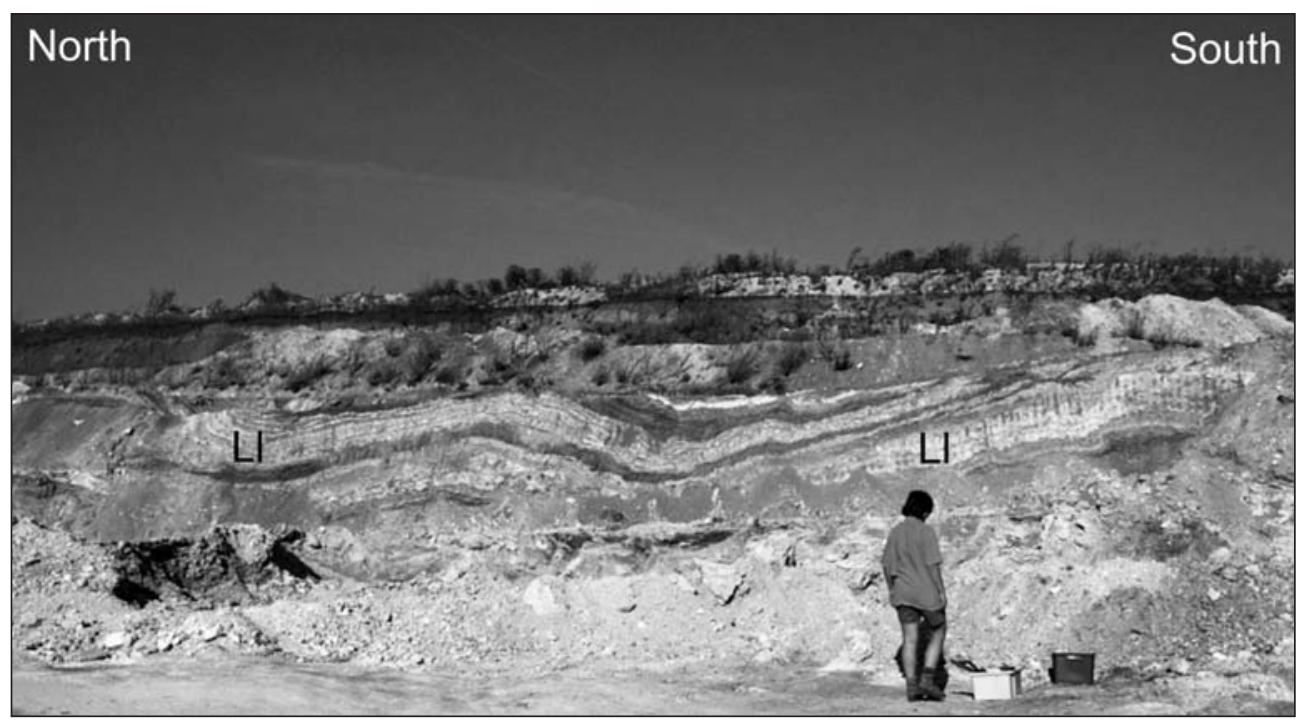

Fig. 7 - Maars with thick laminated lacustrine sequences (LI) such as the Pula maar in western Hungary. The diatreme filling water saturated sediments go through a gradual loss of water, compaction, and reorganisation of entire blocks in the volcanic conduit that initiate a continuous subsidence of the accumulated sediments in the crater. This subsidence process truncates the laminated sediments of the crater-lake.

Fig. 7 - Maars contenant d'épaisses séries lacustres laminées (L1), comme celui de Pula en Hongrie occidentale. Les sédiments saturés en eau remplissant le diatrème subissent une perte en eau graduelle, une compaction et une réorganisation de pans entiers à l'intérieur du conduit volcanique. Le résultat de ces processus est la subsidence continue des sédiments remplissant le cratère. A cause de celle-ci, la disposition des sédiments en forme de lamines a été perturbée et ils sont tronqués.
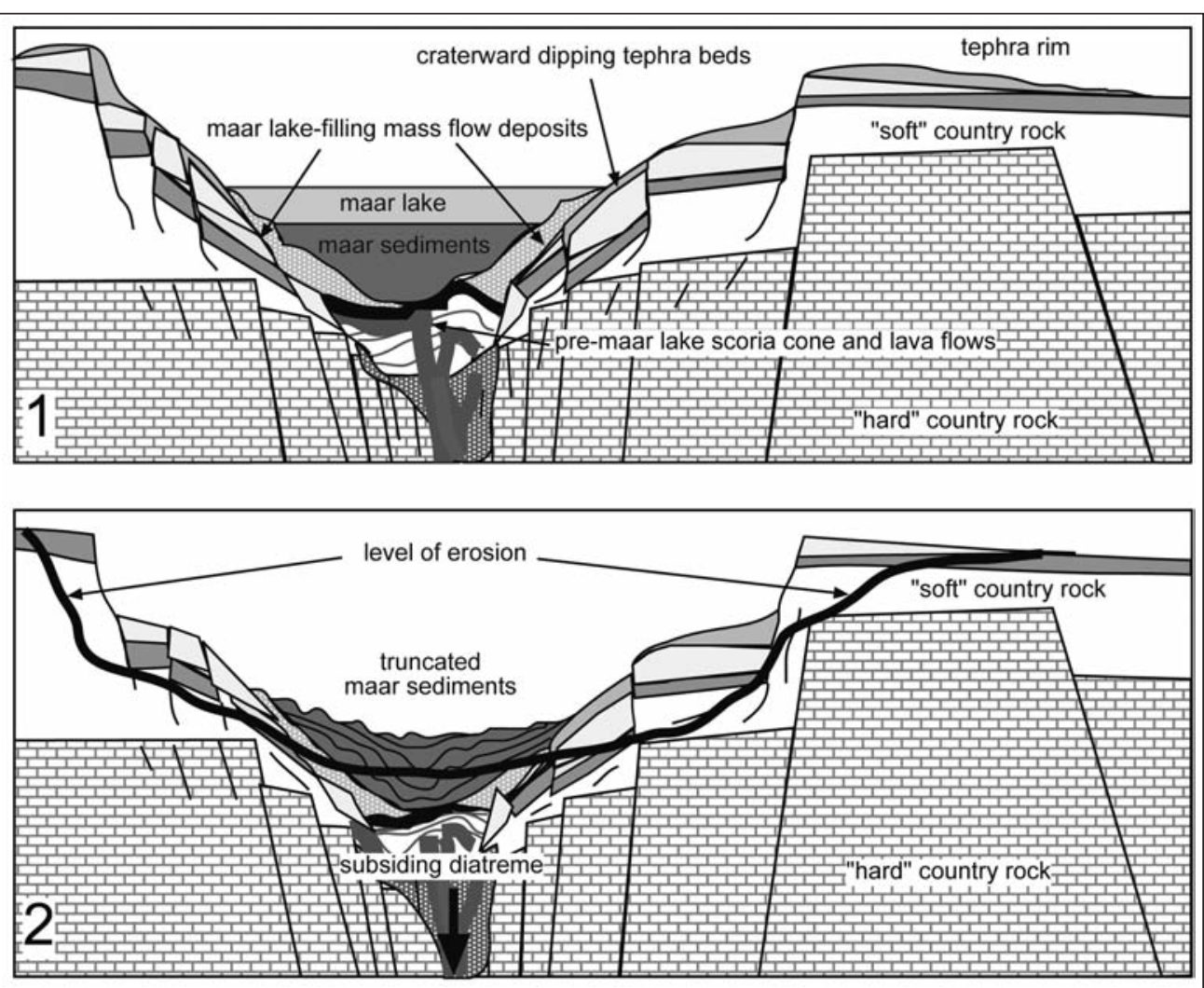

the basin settings from those created by volcanic eruptions, it is important to reconstruct the landscape evolution of the region. Only the correct identification of 3D relationships between volcanic facies associated with the volcanic complexes allows a correct reconstruction of the syn-volcanic landscape (fig. 10). Intra-crateric subaqueous volcanic eruptions in deep maars tend to produce pyroclastic mounds that are located significantly below the syn-eruptive paleosurface.

\section{'Soft substrate' environment versus 'hard rock' environment}

It is commonly reported that the shape and geometry of small volcanoes strongly depends on the 'rock or substrate' environment through which the volcano erupts (Lorenz, 2003a, b). In general, in soft rock sediment environments, tuff rings and maars tend to develop broad, flat, and shallow craters. By

Fig. 8 - A generalized model to represent the importance of recognizing crater subsidence in re-establishing the syn-eruptive level of paleosurfaces. On ' $A$ ' an original scenario shows the position of non-deformed lacustrine sediments in comparison to the syn-eruptive paleosurfaces. On ' $\mathrm{B}$ ' the position of sedimentary units after subsidence is shown. The central lacustrine deposits may subside a few tens of metres deeper in comparison to their syn-depositional position. Thick line on B represents surface after erosion.

Fig. 8 - Un modèle général montre l'importance de l'identification de la subsidence des cratères pour la reconstruction du niveau de la paléosurface au moment de l'éruption. En A le scénario initial indique la position des sédiments lacustres non déformés par rapport à la paléosurface syn-éruptive. En B apparaît la position des séries sédimentaires à la suite de la subsidence. Les dépôts lacustres au centre du cratère peuvent subir une subsidence de quelques dizaines de mètres par rapport à leur position synsédimentaire. La ligne épaisse en $B$ représente la surface après l'érosion. 
Fig. 9 - Overview of a dyke and sill complex and associated scoria cone remnant developed inside of a large maar complex in Uzsa, western Hungary.

Fig. 9 - Vue générale d'un système de dykes et de sills complexe, associé à des vestiges de cônes de scories, dans le grand maar d'Uzsa en Hongrie occidentale.

contrast, in 'hard' rock environments the crater walls stay stable, and the root zone may reach greater depths (Lorenz, 2003a). To distinguish volcanic landforms associated with specific host rock environments, it is important to properly identify eroded volcanic fields. Quite often only the diatreme is preserved in eroded volcanic fields. Pyroclastic deposits and rocks preserved in the diatreme will reflect the excavation depth of country rocks, the level of fragmentation/explosion and the total contribution of the country rocks to the formation of the volcano (fig. 11). In the case of shallow depth explosion and fragmentation, the pyroclastic rocks are usually juvenile fragment-dominated and mixed with small volumes of unconsolidated ("soft") rocks that may be incorporated into the volcanic debris. When the explosion takes place in a 'soft' substrate at deeper levels, the erupted tephra enclose rock and mineral fragments from the unconsolidated 'soft' substrate. By

Fig. 10 - General model of the erosion of maar volcanic complexes in western Hungary. A: subaqueous vent(s) in water filled maars; B: scoria cone and associated lava flow(s) erupted in water filled maar; C: scoria cone erupted in a dry maar feeding lava lake. Continuous black lines represent potential erosion level in each case. Note the significantly different meanings of the preserved paleosurfaces covered by lava units.

Fig. 10 - Modèle général de l'érosion des complexes de maars en Hongrie occidentale. A : cheminée volcanique subaquatique dans des maars remplis d'eau; $B$ : cône de scories avec des coulées de lave épanchées dans des maars remplis d'eau ; C : cône de scories au sein de lacs de lave dans un maar sec. Les lignes noires continues représentent le niveau d'érosion potentiel dans chaque cas. On notera les différences de signification géomorphologique des paléosurfaces fossilisées par les coulées de lave.
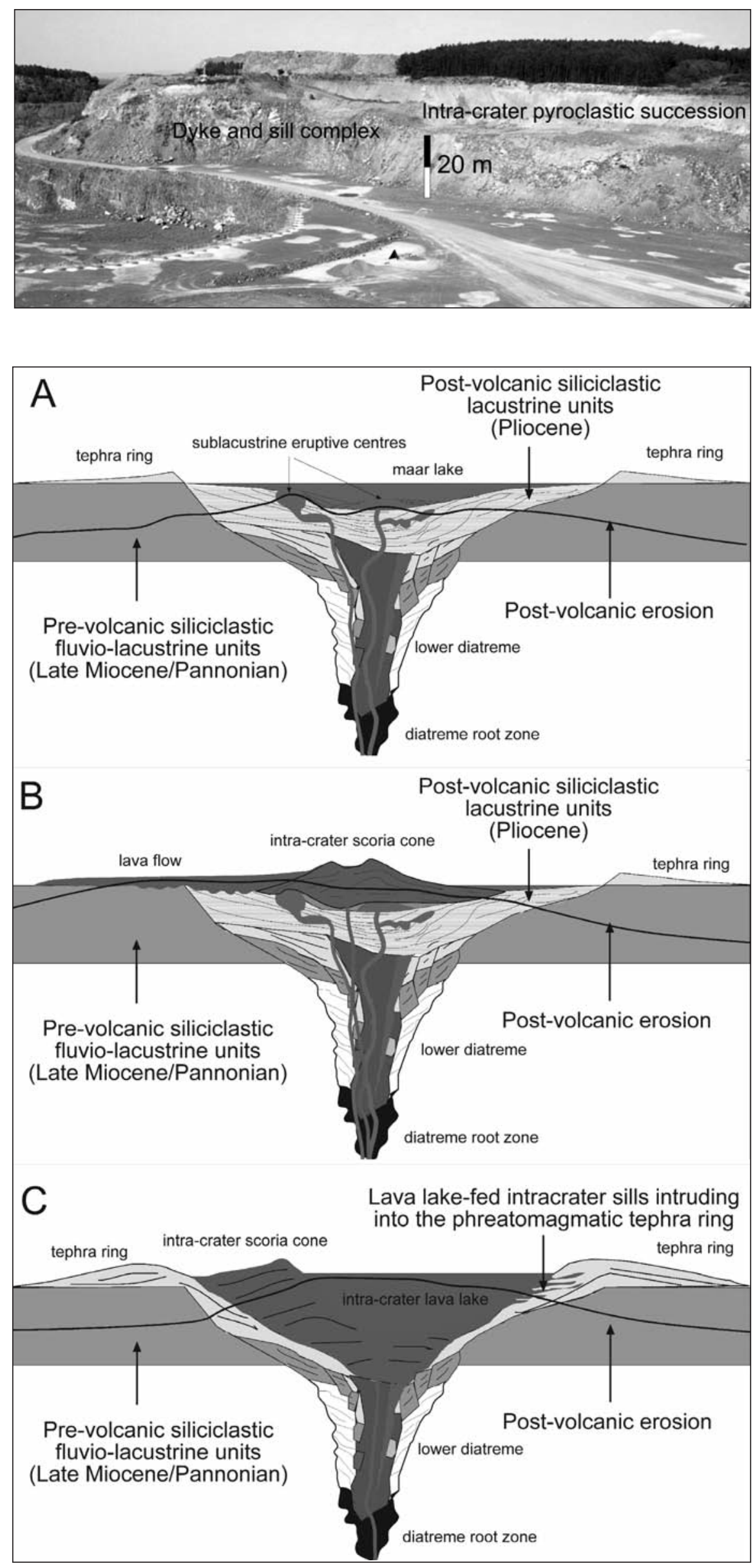
Fig. 11 - Textural evidences based on pyroclastic rocks to establish the country rock type ('hard' - coherent vs. 'soft' - unconsolidated rock) into the maar-diatreme volcano erupted. At outcrop scale, bedded phreatomagmatic tephra contains a large volume of hard country rocks (arrows) (A) disrupted by the sub-surface phreatomagmatic explosions (e.g. Pula maar) and commonly accumulated in scour fills of massive base surge beds (lens cap on 'A' is $5 \mathrm{~cm}$ across). Fine grained cross laminated base surge (Clbs) tephra (tuff) is also rich in accidental lithic fragments. Pyroclastic rocks (e.g. Pula maar) are rich in angular large country rock fragments circled in photo (B). Tephra of maar-diatre-
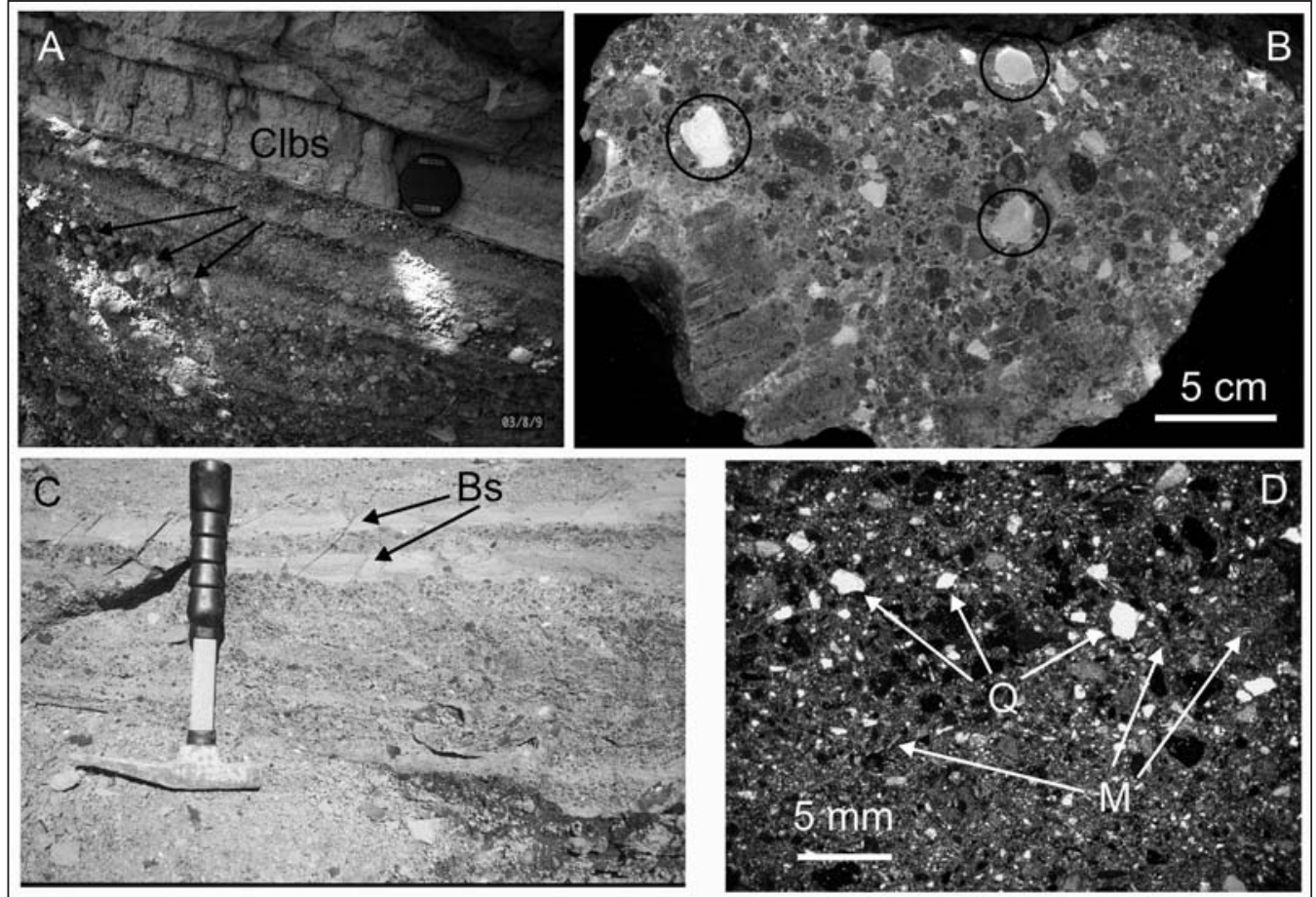
me volcanoes erupted in

'soft' rock environment such as the Kissomlyó tuff ring have fine-grained matrix commonly deposited from base surge (Bs) currents that is rich in mineral phases derived from the 'soft' country rock units (C) (Hammer is $30 \mathrm{~cm}$ long on ' $\mathrm{C}$ ') In microtexture (cross nicol photomicrograph of a phreatomagmatic lapilli tuff from Kissomlyó tuff ring) such pyroclastic rocks are rich in quartzofeldspathic fragments (e.g. muscovite cf $M$; quartz cf $Q$ ) derived from the 'soft' country rock (D).

Fig. 11 - Les textures des roches pyroclastiques fournissent des arguments pour la reconnaissance du type de roches encaissantes (dure - cohérente versus tendre - non consolidée) au moment de l'éruption du volcan de type maar et diatrème. À l'échelle de l'affleurement, les strates de téphras phréatomagmatiques contiennent en grande quantité des roches encaissantes (flèches) (A) fragmentées par les explosions hydromagmatiques (par exemple le maar de Pula) et souvent accumulées dans les couches massives des dépôts de déferlantes basales (couvercle de l'objectif, $5 \mathrm{~cm}$ de diamètre). Le tuf à feuilletage entrecroisé et à grains fins de la déferlante basale (Clbs) est aussi accessoirement riche en fragments lithiques. Les roches pyroclastiques (par exemple, à Pula) sont riches en gros blocs anguleux de roches encaissantes (encerclées sur la photo B). Les téphras comme celles de l'anneau de tuf de Kissomlyó associées à des maars et diatrèmes inscrits dans des roches meubles, ont une matrice à grains fins déposée par les déferlantes basales (Bs), qui est riche en minéraux issus de ces roches encaissantes (photo C avec marteau de $30 \mathrm{~cm}$ ). Au microscope (tuf à lapilli de l'anneau de tuf de Kissomlyó, photo nicols croisés) la texture de ces roches pyroclastiques montre des fragments de quartz, micas et feldspaths (par exemple muscovite cf. M; quartz cf. Q) qui proviennent des roches encaissantes meubles (D).

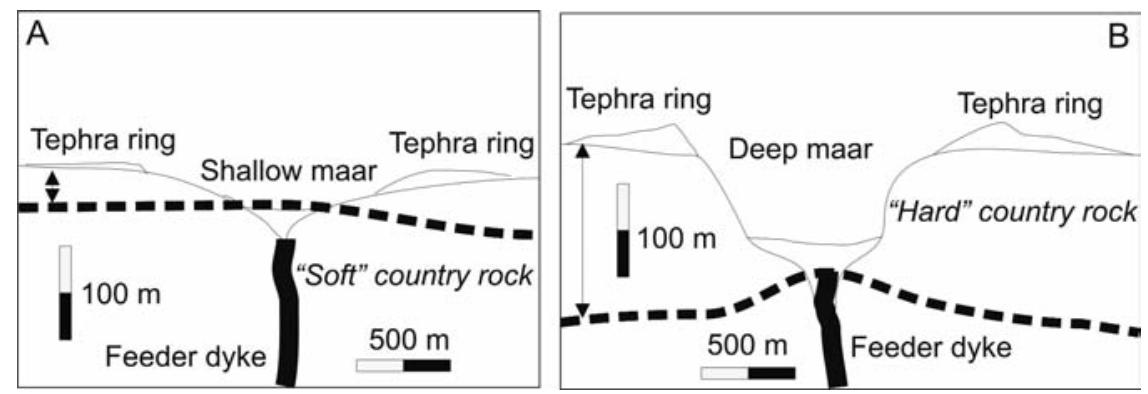

Fig. 12 - In 'soft' rock environment (A) maars are broad, their tephra rings low and their diatremes shallow. In contrast, in 'hard' rock environment, maars are deep, their tephra ring could be thick (tens of metres) and the diatreme may be deep (B). The recognition of such eruptive rock environment may refine the reconstruction of the position of the syn-eruptive paleosurface in comparison to the preserved diatreme facies rocks.Dashed lines represent erosional surfaces. Thick blakc lines are coherent magmatic bodies (feeder dykes, lava flows or sills.

Fig. 12 - Dans des roches meubles (A), les maars sont larges, l'anneau de téphras est bas, le diatrème est peu profond. En revanche, dans des roches cohérentes, les maars sont profonds, l'anneau de téphras est épais (des dizaines de mètres) et le diatrème peut être profond (B). L'analyse de l'environnement de telles roches volcano-sédimentaires, comparée aux faciès des roches des diatrèmes, peut aider à affiner la reconstitution de la paléosurface syn-éruptive. Les tiretés représentent les surfaces actuelles après érosion. Les lignes noires épaisses désignent des corps magmatiques (dykes d'alimentation, coulées de lave ou sills).

contrast, the erupted tephra will contain rock fragments in the case of deep level explosions occurring in coherent ('hard') rock units. Estimates of the total proportion of accidental lithics and their lithological characteristics could be a solid base to reconstruct the geometrical parameters of the original volcanic landform (Németh, 2003). This is because in eroded maars the only preserved part of the volcano is the diatreme, the determination of its rock type can help to esta- 
blish the characteristics of the original volcanic landform. The reconstruction of a volcano that erupted in 'soft' rock environment generally shows a broad shape with a shallow crater (fig. 12). By using this method, the estimation of the initial position of the syn-eruptive landscape would suggest less erosion than which is deduced by considering only the preserved diatreme geometry. When there is evidence to support the 'hard' rock hypothesis, the size of the preserved diatreme may indicate a deeper position in the syn-volcanic succession (fig. 12). Thus, any estimate of syn-volcanic landscape position would be higher than is suggested by the diatreme geometry. In the western Pannonian Basin, diatremes in the Little Hungarian Plain Volcanic Field (fig. 1) represent volcanoes that erupted through 'soft' substrate. Therefore, their current position represents a shallow depth below the syn-volcanic landscape. By contrast, in the Bakony - Balaton Highland Volcanic Field (fig. 1), eruptions occurred through 'hard' rock units. Thus the preserved diatremes contain mainly volcanic conduit filling rocks that are found at deeper levels below the syn-volcanic landscape, than can be estimated from the simple geometrical dimensions of the diatreme itself.

\section{Conclusion}

Phreatomagmatic volcanoes generally form in low-lying areas or valleys. By contrast, magmatic explosive eruptive centres and extensive lava fields are usually found in elevated areas with limited water availability. However, lava flows are commonly confined to valleys or stopped behind syn-volcanic geomorphic barriers. Lava flows may not leave their source vent zone, forming lava lakes by filling the wide craters of phreatomagmatic volcanoes. Distribution of the various types of vents gives vital information on the syn-volcanic landscape drainage system, as well as its physiography. Identification of widespread phreatomagmatism in many volcanic fields suggests extensive surface and ground-water availability in the region during periods of volcanic activity. We suggest that instead of using a geometrical approach to establish the original position of the syn-eruptive paleosurfaces, that a careful study of the preserved pyroclastic rocks and their facies relationships should be undertaken. This should lead to a better understanding of: (1) the eruptive environment into which the volcano erupted, (2) the distinction between extra- and intracrater processes, (3) the recognition of textural features such as peperite occurrence that may be indicative of environmental conditions where lava effusion occurred, and (4) the identification of the country rocks underlying and surrounding the erupting volcanoes. With these considerations taken into account the reconstruction of the syn-volcanic eruptive paleosurfaces should be more realistic.

\section{Acknowledgements}

This is the result of research work funded by the Magyary Zoltán Post-doctoral Fellowship and the Hungarian Science Foundation OTKA F 043346 (KN). This project is also part of a NZ FRST Post-doctoral research grant (KN) at Massey University (MAUX0405) to study mafic explosive volcanism. The manuscript has greatly benefited from the reviews of P. Boivin, J. Lecointre and A. Duncan. Editorial work of J-C. Thouret is greatly appreciated.

\section{References}

Aranda-Gomez J.J., Luhr J.F. (1996) - Origin of the Joya Honda maar, San Luis Potosi, Mexico. Journal of Volcanology and Geothermal Research 74, 1-18.

Balogh K., Árva-Sós E., Pécskay Z., Ravasz-Baranyai L. (1986) - K/Ar dating of post-Sarmatian alkali basaltic rocks in Hungary. Acta Mineralogica et Petrographica, Szeged 28, 75-94.

Balogh K., Itaya T., Németh K., Martin U., Wijbrans J., Than N.X. (2005) - Study of controversial K/Ar and ${ }^{40} \mathrm{Ar} /{ }^{39} \mathrm{Ar}$ ages of the Pliocene alkali basalt of Hegyestu, Balaton Highland, Hungary: a progress report. Mineralia Slovaca 37, 298-301.

Balogh K., Németh K. (2005) - Evidence for the neogene smallvolume intracontinental. volcanism in western Hungary: K/Ar geochronology of the Tihany Maar volcanic complex. Geologica Carpathica 56, 91-99.

Connor C.B., Conway F.M. (2000) - Basaltic volcanic fields. In Sigurdsson H., Houghton B.F., McNutt S.R., Rymer H., Stix J. (Eds), Encyclopedia of Volcanoes, San Diego, Academic Press, 331-343.

Csillag G., Németh K., Martin U., Goth K., Suhr P. (2004) - 3D architecture of a Pliocene maar volcano on the basis of drill core data and its implication for syn-volcanic geomorphology, Pula Maar, western Pannonian Basin. Abstract Volume of the 2nd International Maar Conference, Occasional Papers of the Geological Institute of Hungary 203, 50.

Hooten J.A., Ort M.H. (2002) - Peperite as a record of earlystage phreatomagmatic fragmentation processes: an example from the Hopi Buttes volcanic field, Navajo Nation, Arizona, USA. Journal of Volcanology and Geothermal Research 114, 95-106.

Kázmér M. (1990) - Birth, life and death of the Pannonian Lake. Palaeogeography, Palaeoclimatology, Palaeoecology, 79, 171-188.

Konecny V., Lexa J. (2000) - Pliocene to Pleistocene alkali basalt diatremes and maars of Southern Slovakia: a common model for their evolution. Terra Nostra 6, 220-232.

Lorenz V. (1986) - On the growth of maars and diatremes and its relevance to the formation of tuff rings. Bulletin of Volcanology 48, 265-274.

Lorenz V. (1987) - Phreatomagmatism and its relevance. Chemical Geology 62, 149-156.

Lorenz V. (2000) - Formation of the root zones of maar-diatreme volcanoes. Terra Nostra 6, 279-284.

Lorenz V. (2003a) - Maar-diatreme volcanoes, their formation, and their setting in hard-rock or soft-rock environments. Geolines - Journal of the Geological Institute of AS Czech Republic $15,72-83$.

Lorenz V. (2003b) - Syn- and post-eruptive processes of maar-diatreme volcanoes and their relevance to the accumulation of post-eruptive maar crater sediments. [Maar-diatréma vulkánok szín-és poszt-eruptív folyamatai, azok kapcsolata a poszt-eruptív 
maar kráter-tavi üledékekkel] [in English with Hungarian abstract]. Földtani Kutatás (Quaterly Journals of the Geological Survey of Hungary), Budapest, XL, 13-22.

Lorenz V., Haneke J. (2004) - Relationship between diatremes, dykes, sills, laccoliths, intrusive-extrusive domes, lava flows, and tephra deposits with unconsolidated water-saturated sediments in the late Variscan intermontane Saar-Nahe Basin, SW Germany. In Breitkreuz C., Petford N. (Eds), Physical Geology of Subvolcanic Systems - Laccoliths, Sills, and Dykes, Oxford, Blackwell Sciences, 234, 75-124.

Magyar I., Geary D.H., Muller P. (1999) - Paleogeographic evolution of the Late Miocene Lake Pannon in Central Europe. Palaeogeography, Palaeoclimatology, Palaeoecology 147, 151-167.

Martin U., Németh K. (2004) - Mio-Pliocene phreatomagmatic volcanism in the western Pannonian Basin. Budapest, Geological Institute of Hungary, Geologica Hungarica, Series Geologica $26,193 \mathrm{p}$.

Martin U., Németh K. (2005) - Eruptive and depositional history of a Pliocene tuff ring that developed in a fluvio-lacustrine basin: Kissomlyó Volcano (Western Hungary). Journal of Volcanology and Geothermal Research 147, 342-356.

Németh K. (2003) - Calculation of long-term erosion in Central Otago, New Zealand, based on erosional remnants of maar/tuff rings. Zeitschrift für Geomorphologie 47, 29-49.

Németh K., Martin U. (1999) - Late Miocene paleo-geomorphology of the Bakony-Balaton Highland Volcanic Field (Hungary) using physical volcanology data. Zeitschrift für Geomorphologie 43, 417-438.

Németh K., White J.D.L. (2003) - Reconstructing eruption processes of a Miocene monogenetic volcanic field from vent remnants: Waipiata Volcanic Field, South Island, New Zealand. Journal of Volcanology and Geothermal Research 124, 1-21.

Németh K., White J.D.L., Reay A., Martin U. (2003) - Compositional variation during monogenetic volcano growth and its implications for magma supply to continental volcanic fields. Journal of the Geological Society of London 160, 523-530.
Németh K., Csillag G., Martin U. (2002) - Pliocene crater lake deposits and soft-sediment deformation structures associated with a phreatomagmatic volcano: Pula maar, western Hungary. Geologica Carpathica 53, special issue, 41-43, CD-version

Németh K., Martin U., Harangi S. (2001) - Miocene phreatomagmatic volcanism at Tihany (Pannonian Basin, Hungary). Journal of Volcanology and Geothermal Research 111, 111-135.

Skilling I.P., White J.D.L., McPhie J. (2002) - Peperite: a review of magma-sediment mingling. Journal of Volcanology and Geothermal Research 114, 1-17.

Suhr P., Lorenz V., Goth K. (2004) - Subsidence within and above maar-diatreme volcanoes. Abstract Volume of the 2nd International Maar Conference, Occasional Papers of the Geological Institute of Hungary 203, 94.

Vespermann D., Schmincke H.-U. (2000) - Scoria cones and tuff rings. In Sigurdsson H., Houghton B.F., McNutt S.R., Rymer H., Stix J. (Eds), Encyclopedia of Volcanoes, San Diego, Academic Press, 683-694.

White J.D.L. (1990) - Depositional architecture of a maar-pitted playa - sedimentation in the Hopi Buttes Volcanic Field, Northeastern Arizona, USA. Sedimentary Geology 67, 55-84.

White J.D.L. (1991a) - The depositional record of small, monogenetic volcanoes within terrestrical basins. In Fisher R.V., Smith G.A. (Eds), Sedimentation in Volcanic Settings, Tulsa (Oklahoma), Society for Sedimentary Geology 45, 155-171.

White J.D.L. (1991b) - Maar-diatreme phreatomagmatism at Hopi Buttes, Navajo Nation (Arizona) USA. Bulletin of Volcanology 53, 239-258.

White J.D.L., McPhie J., Skilling I. (2000) - Peperite: a useful genetic term. Bulletin of Volcanology 62, 65-66.

White J.D.L., McClintock M.K. (2001) - Immense vent complex marks flood-basalt eruption in a wet, failed rift: Coombs Hills, Antarctica. Geology 29, 935-938.

Article soumis le 28 février 2006, accepté le 26 janvier 2007. 



\section{Pitfalls in erosion level calculation based on remnants of maar and diatreme volcanoes}

Németh, Károly

2007

http://hdl.handle.net/10179/9746

22/04/2023 - Downloaded from MASSEY RESEARCH ONLINE 